\title{
Chemical and Biological Treatment of Fish Canning Wastewaters
}

\author{
Raquel O. Cristóvão, Cidália M. S. Botelho, Ramiro J. E. Martins, and Rui A. R. Boaventura
}

\begin{abstract}
The main environmental problems of fish canning industries are high water consumption and high organic matter, oil and grease and salt content in their wastewaters. This work aims to analyze the situation of different plants located north of Douro river, in Portugal, in order to propose various solutions to their problems. Thus, initially it was made an identification and implementation of prevent and control pollution measures within the industrial units in order to reduce water consumption, minimize the wastewater production and reduce the pollutant load to treat. Then, the wastewater treatability was evaluated through a sedimentation and coagulation-flocculation process and through an aerobic biological degradation. In the sedimentation and coagulation-flocculation process two organic coagulants (RIPOL 070 and RIFLOC 1815), commonly used in wastewater treatment, were tested, leading to good results, especially in terms of oil and grease and total suspended solids removals. The best suspended solids removal efficiencies were $53 \%$ and $79 \%$, using $400 \mathrm{mg} / \mathrm{L}$ of RIPOL 070 and $150 \mathrm{mg} / \mathrm{L}$ of RIFLOC 1815 , respectively. At these dosages, both coagulants demonstrated excellent oil and grease removals, about $99 \%$ for RIFLOC 1815 and $88 \%$ for RIPOL 070 . The aerobic biological treatment with activated sludge proved to be very adequate to organic matter removal. Two feed flow rates were tested and the highest TOC removal efficiency $(96 \%)$ was verified with the lowest one $(0.75$ $\mathrm{L} / \mathrm{h})$, corresponding to a longer hydraulic retention time $(8 \mathrm{~h})$. So, the proposed sequential treatment, combining physico-chemical and biological processes, proved to be an effective alternative to start the fish canning wastewaters treatment for further reuse in the industrial process.
\end{abstract}

Index Terms-Biological treatment, coagulation-flocculation, integrated pollution prevention and control (IPPC), fish canning wastewater treatment.

\section{INTRODUCTION}

The canning sector is generally seen as the main segment of the fishing manufacturing industry at national level. In

Manuscript received May 11, 2012; revised July 11, 2012. This work was partially supported by project PEst-C/EQB/LA0020/2011, financed by FEDER through COMPETE - Programa Operacional Factores de Competitividade and by FCT - Fundação para a Ciência e a Tecnologia and by project ValorPeixe - Valorização de Subprodutos e Águas Residuais da Indústria de Conservas de Peixe, project in co-promotion I\&DT QREN, ${ }^{\circ}$ 13634, financed by FEDER through POFC - Programa Operational Factores de Competitividade.

R. O. Cristóvão and C. M. S. Botelho, and R. A. R. Boaventura are with the Laboratory of Separation and Reaction Engineering (LSRE), Associate Laboratory LSRE/LCM, Department of Chemical Engineering, Faculty of Engineering, University of Porto, Rua do Dr. Roberto Frias, 4200-465 Porto, Portugal (e-mail: raquel.cristovao@fe.up.pt, rmartins@ipb.pt. bventura@fe.up.pt).

R. J. E. Martins is with the Department of Chemical and Biological Technology, Superior School of Technology, Polythecnic Institute of Bragança, Campus de Santa Apolónia, 5301-857 Bragança, Portugal (e-mail: rmartins@ipb.pt).
1938 there were 152 canneries in Portugal which produced about 34,000 tons of canned fish. Currently there are 20 plants in operation producing 58,500 tons of canned fish [1] and seven of them are located north of Douro River.

The fish canning industry consumes a large amount of water in operations such as cleaning, washing, cooling, thawing, ice removal, etc. [2]. Consequently, this sector also generates large quantities of wastewater in which the treatment is particularly difficult due to the high content of organic matter and salts and to the significant amount of oil and grease they present [3]. These factors, together with the fact that these effluents present significant variations depending on the production process and on raw material processed, makes difficult to meet the emission limit values (ELVs) for industrial wastewaters (Decree-Law No. 236/98) and to deal with this problem in a sustainable manner. These effluents are often subjected to a pre-treatment before discharge to the sewage system for further treatment at an urban wastewater treatment plant. However, integrated pollution prevention and control (IPPC) measures should be implemented upstream in order to reduce the effluent volume and pollution load, eliminate, reduce or valorize certain hazardous substances [4], thus increasing the efficiency of water use (Decree-Law No. 173/2008). There is also a need, for both economic and environmental sustainability reasons, to consider the effluents treatment in order to obtain water with quality requirements that allow its reuse or recycling for industrial process [2].

Some wastewater streams may be segregated and processed separately in order to obtain subproducts, thereby reducing the overall effluent pollution load. For example, different processes have been described in the literature for the treatment of wastewaters with high oil and grease content. The most commonly used are: chemical destabilization [5], membrane separation processes [6] and electrochemical methods [7]. The principle of chemical destabilization method consists on the destabilization of the emulsion by cancelling the energy barrier that exists between the oil droplets. This is obtained by the addition of chemical compounds that neutralized the electric charges which cause the repulsion of the droplets. The destabilized droplets are then agglomerated by coalescence or flocculation and, after that, separated by decantation, flotation, centrifugation or filtration. The three chemical groups commonly used for colloidal particles destabilization are: metal salts [8], acids [9] and synthetic polyelectrolytes [10]. The best choice for a particular application depends on the system.

Regarding the organic matter degradation, the food industries wastewaters are conventionally submitted to biological treatments, as their wastewaters are normally rich 
in organic matter and nutrients. The main aim of this treatment is mainly to reduce the organic matter content using microorganisms either by oxidation or incorporation into new cells. The biochemical oxygen demand (BOD) and chemical oxygen demand (COD) significantly decrease as the result of the microbiological activity. The most widely used biological treatments involve anaerobic or aerobic processes. COD removal of fish processing wastewaters has been studied involving anaerobic digestion processes [11],[12] and hybrid bioreactors with ultrafiltration membrane process [13],[14]. Mora et al. [15] studied the application of the Anammox process (autotrophic anaerobic oxidation of ammonia) after anaerobic digestion and treatment in a Sharon reactor. In relation to aerobic treatment, extended aeration activated sludge systems have been used most of the time [16]. In these systems sludge age should be maintained at 18-20 days. However, the performance of this treatment is greatly influenced by room temperature. Under cold weather conditions, the biological activity may decrease significantly, decreasing, consequently, the performance efficiency of the system [17].

This work aims to enable canned fish industries from northern Portugal to reorganize their production processes in order to make them more eco-efficient, through analysis and evaluation of their wastewaters and implementation of IPPC measures. Finally, since it is intended to obtain water with quality parameters that allow its reuse or recycling within the industrial plant, the wastewater treatment study was initiated with the following treatment sequence: sedimentation, coagulation-flocculation process and biological degradation. However, in order to evaluate the removal efficiencies of each treatment method, in this work the chemical treatment and the biological degradation by aerobic microorganisms were studied separately. So, the wastewater treatment was started with the sedimentation and chemical coagulation/flocculation tests to evaluate essentially the removal of oil and grease (O\&G) from fish canning wastewaters. The treatment efficiencies were assessed in terms of chemical oxygen demand (COD), total organic carbon (TOC) and O\&G removals. Concerning the organic matter removal, the wastewater was subjected to biological treatment using activated sludge. The reaction takes place in the reactor between the microorganisms and the wastewater ensuring a dissolved oxygen concentration in the aqueous phase which allows the operation in aerobic conditions. The main products are carbon dioxide, water and new cells [18]. So, the performance obtained depends on a proper adaptation of the biomass. The treatment efficiencies were assessed in terms of TOC removal.

\section{Fish CANNING PROCESS}

In Fig. 1 is presented, as an example, the production process flowchart of a cannery in northern Portugal, where it is shown the water use in the various steps of the process, the main sources of wastewaters generated and the most important contaminants. The production process begins with the reception of raw materials (fish, sauces and packaging materials). In the fishing boats, the fish is kept in water tanks. The most common method for unloading the fish to the plant is by pumping and/or transport with seawater. At the factory, the water drains out and the fish is weighed and stored again in salted water tanks. Sea water can also be used to transport the fish in some of the processes within the plant. The main waste stream resulting from this operation is the water used in the transport, along with water used for preservation in the boats. Wastewaters from this stage contain blood, fish, rocks and sand from the fishing boats tanks. Depending on the fish type and on the discharge conditions, this wastewater can reach $20-25 \%$ of the total organic load that the canned fish industry generates [19].

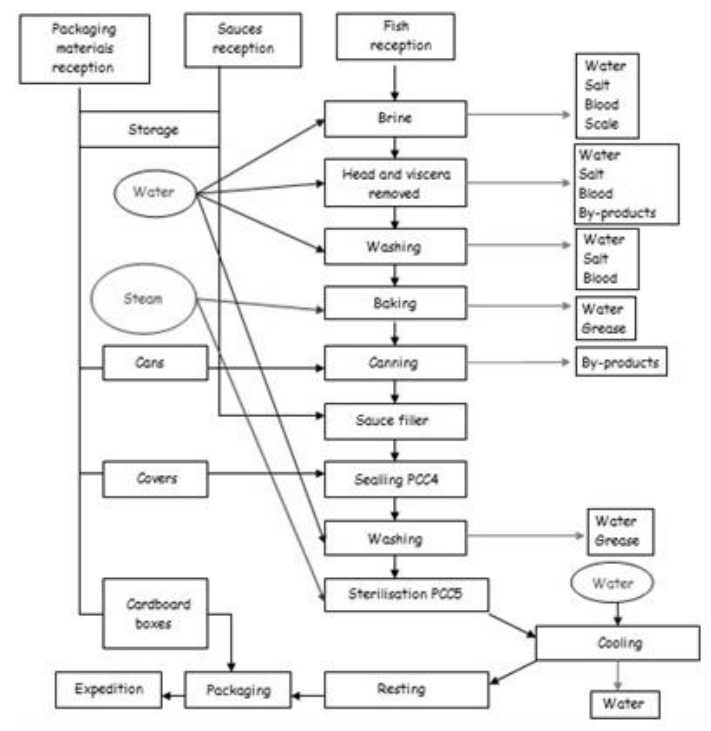

Fig. 1. Fish canning industry A flowchart.

Then the packaging materials and sauces are stored and the fish is placed in brine, a process that requires water and produces wastewaters especially rich in salt, blood and scales. Following is the process of removing unwanted fish parts: head and viscera removal, to which is also necessary the use of water. From this process results an effluent mainly contaminated with salt, blood and fish waste that cannot be used as food. In the fish washing process water is used in abundance. To ensure that the washing is sufficient, the ratio should be at least 1:1, but in practice, however, the quantity of water used doubles. From this operation results a wastewater containing mainly blood, oil, flakes, salt and fish tissues. The main characteristic of the washing waste streams is that they have low contamination levels in relation to other streams, however, the wash water becomes an important volume in relation to the total wastewater of the plant

The following process corresponds to the cooking and subsequent cooling of the fish. The fish cooking is done through direct contact with steam. After cooking time, the water produced is drained and the fish are cooled by spraying. There are two parts that contribute to the water generated by this process: one originated from the cooking, which has a very high concentration of organic material and fats and other from washing and cooling (usually seawater) that has low organic load, but has a high salinity. Hence, the fish goes to canning, sauces addition, spiking and cans washing processes. This final wash leads also to an effluent that has, essentially, fish fat. Finally, the cans sterilization is carried out with steam and its cooling is performed with water, which also 
results in a wastewater. In addition to all these wastewaters produced, liquid spills occur due to shipping, handling, canning and cleaning of equipment, involving waste of raw materials.

\section{MATERIALS AND METHODS}

\section{A. Wastewater Characterization}

Five litres of wastewater from several fish canning industries from northern Portugal were collected. Standard methods for the examination of wastewater [20] were adopted for the measurement of total suspended solids (TSS), volatile suspended solids (VSS), total organic carbon (TOC), chemical oxygen demand (COD), biochemical oxygen demand (BOD), oil and grease (O\&G), total phosphorus $\left(\mathrm{P}_{\text {total }}\right)$, total soluble nitrogen $\left(\mathrm{N}_{\text {total soluble }}\right)$ and ammoniacal nitrogen $\left(\mathrm{N}_{\mathrm{ammoniacal}}\right)$.

\section{B. Coagulation/Flocculation treatment}

Before coagulation-flocculation treatment itself, a sedimentation test was made, where the effluent was left in graduated cylinders for a 2 hours period. The graduated cylinders are provided with a sampling port, $10 \mathrm{~cm}$ above the bottom, which allows taking samples directly from the middle layer (Fig. 2). These samples further used in jar tests were then analyzed in terms of TSS, TOC and O\&G parameters. The wastewater characteristics before and after sedimentation test are shown in Table II.

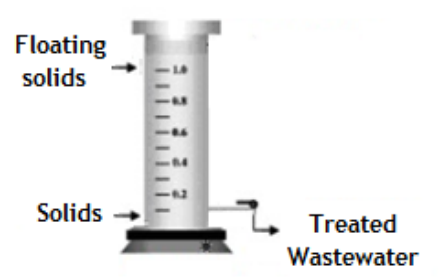

Fig. 2. Graduated cylinder scheme for sedimentation test.

A standard jar test apparatus (Jar tester JLT6, VELP Scientifica) (Fig. 3) was employed for the coagulation-flocculation tests. Two different organic coagulants were tested: RIPOL 070, a diester sulfosuccinate in propane $-1,2$ diol solution, with $50-100 \%$ of sodium dioctil sulfosuccinate and 10-25\% of 1,2-propanediol and RIFLOC 1815 , a polyamine aqueous solution, with $25-50 \%$ of 1,2-ethanediamine polymer with (chloromethyl) oxirane and $\mathrm{N}$-methylmethanamine and $18 \%$ approx. of aluminum polychloride. In order to see if coagulant dosage influenced the wastewater treatment, several dosages were studied: 20-200 mg/L for RIFLOC 1815; 100-400 mg/L for RIPOL 070. Each jar was filled with $300 \mathrm{~mL}$ of sample from the sedimentation test and the coagulant dose for each jar was then added from a working solution of $1 \%$. Then, the experimental procedure consisted of a rapid mixing at 150 rpm for $3 \mathrm{~min}$ and, after that, in order to form flocs, the wastewater was moderately stirred at $20 \mathrm{rpm}$ for $15 \mathrm{~min}$. Finally, a sedimentation stage allowed the flocs formed to settle. The supernatants obtained were then characterized.

These tests were all done with the same fishing washing wastewater sample from fish canning industry A (Table I).

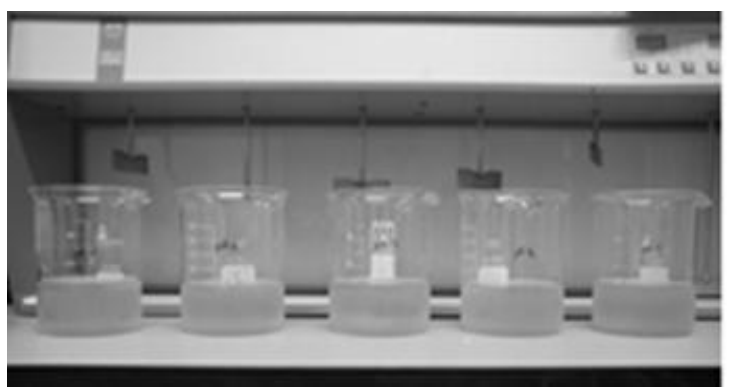

Fig. 3. Jar test with $300 \mathrm{~mL}$ of decanted fish canning wastewater for coagulation/flocculation tests.

\section{Biological Treatment}

The biological treatment was applied to decanted fish washing wastewater from plant $\mathrm{A}$ in order to evaluate the organic matter removal efficiency by activated sludge. As inoculum it was used a sample of suspended biomass from the Freixo municipal wastewater treatment plant (Porto, Portugal).

The experiments for this study were performed in a bio-oxidation system BIO KONTROLL mark 2 model from VITTADINI (Fig. 4) that consists of a feed tank (containing the wastewater to be treated), a biological reactor or aeration tank (C) equipped with diffusers at the bottom to ensure the oxygen supply and the mixing of the whole liquid mass, a secondary sedimentation tank (D) equipped with a sludge recirculation system and a storage tank to the final effluent (treated wastewater). There are also two peristaltic pumps operating at adjustable flow rate: one for reactor feeding $(\mathrm{A})$ and another for sludge recirculation (B).
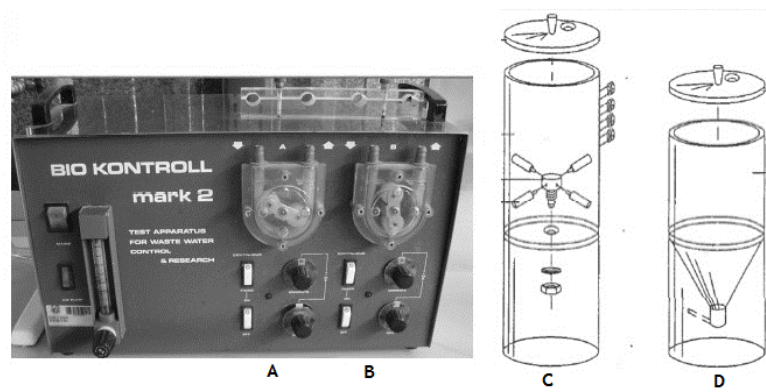

Fig. 4. Equipment of biological treatment with activated sludge.

Before conducting the biological treatment studies themselves, an acclimatization and growing period of the activated sludge used as inoculum was carried out in batch mode during 20 days in order to obtain a biomass concentration in the reactor greater than $1500 \mathrm{mg}_{\mathrm{vss}} / \mathrm{L}$. Once reached this value, the operation was shifted to continuous mode.

In order to verify the influence of flow rate variation in the degradation of the organic matter, the reactor volume was set at $6 \mathrm{~L}$ and two experiments at different flow rates were performed at room temperature: 0.75 and $1.2 \mathrm{~L} / \mathrm{h}$, corresponding to hydraulic retention times (HRT) of 8 and 5 $\mathrm{h}$, respectively. During the tests, the dissolved oxygen concentration into the reactor was kept between 3 and $4 \mathrm{mg} / \mathrm{L}$. The excess of biological sludge produced was removed from the settler and the rest was recirculated to the reactor in order to maintain approximately constant the biomass concentration in the reactor. The treatment efficiency was 
assessed in terms of TOC removal. The specific oxygen uptake rate (SOUR), the VSS and the biomass production rate were also determined for each $\mathrm{HRT}$ and $\mathrm{pH}$ and temperature were also monitored.

\section{RESUlTS AND DisCUSSION}

\section{A. Fish canning Industries Wastewaters Characterization}

The pollution load of fish canning industry wastewaters relies heavily on the type of fish being processed. Moreover, the volume and characteristics of the final effluent change significantly throughout the day, depending on the streams that are being launched: cooking effluents, effluents generated during sterilization, washing effluents, etc.

TABLE I: WASTEWATER COMPOSITION OF VARIOUS INDUSTRIES OF CANNED FISH.

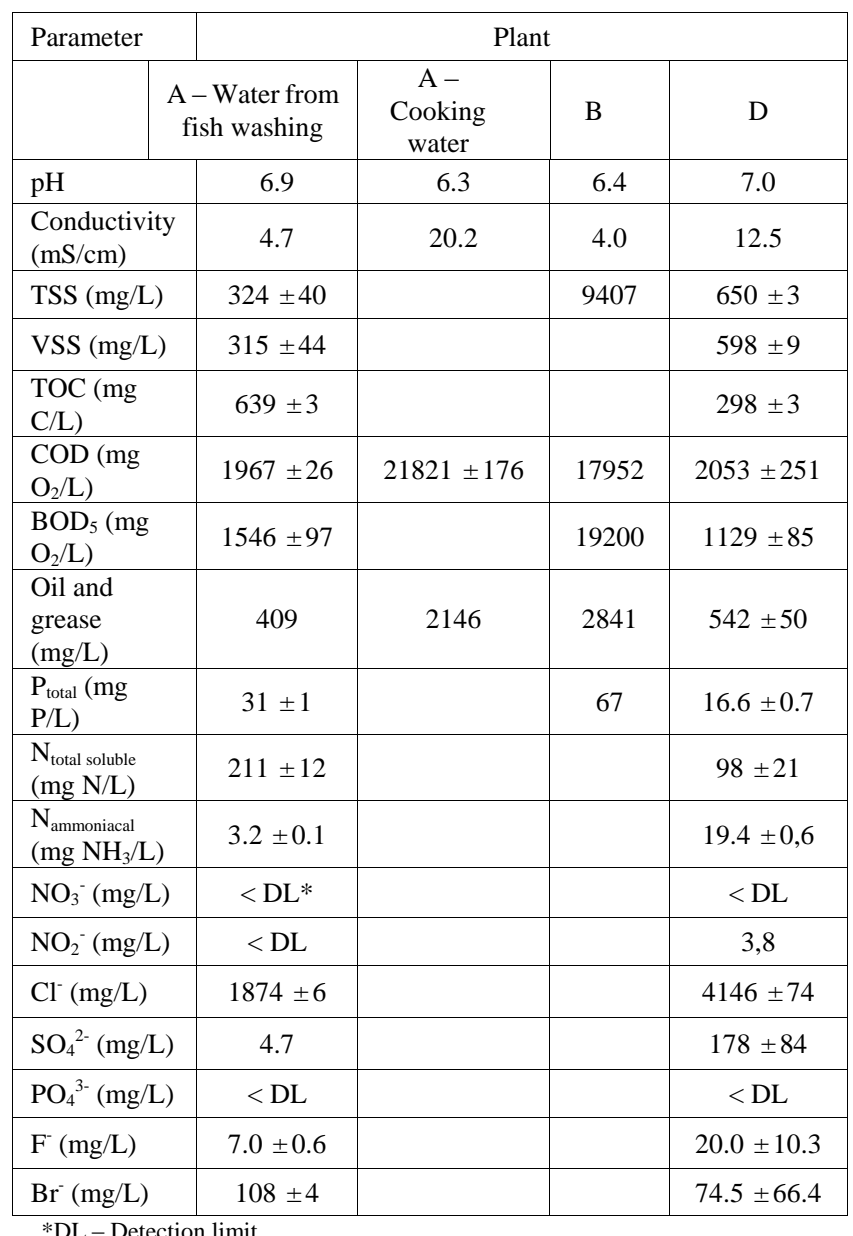

In order to obtain a representative set of information on water use and effluent production in fish canning industry, seven plants were identified at north of the Douro River in Portugal, referred by the letters A to G. The typical value of water consumption in these industries was found to be approximately $15 \mathrm{~m}^{3} /$ ton raw fish, with global values of average daily consumption in the range of $20-300 \mathrm{~m}^{3}$, depending on the plant capacity.

Some of the industries under study already have installed a pre-treatment unit for their effluents, consisting of sieving and sedimentation in the case of company A, elevation by screw conveyor, sieving and flocculation in company B and filtering, retention and settling in the case of company D.
After these treatments, the effluents are discharged directly to the municipal wastewater sewage network. However, most of the time, these effluents do not meet the law requirements for discharge. Table I shows the effluents characteristics from A, $\mathrm{B}$ and $\mathrm{D}$ industries, only after the pre-treatment that they have been subjected to.

\section{B. Integrated Pollution Prevention and Control Measures}

The first step for implementing an integrated solution in an industrial plant is to examine the possibilities to avoid and/or reduce waste at source through the application of measures for cleaner production concerning the raw materials, technological changes, good manufacturing practices, etc.. Most of these preventive measures are easy to implement and have low costs. The application of these measures reduces the volume and the waste content, thereby allowing simpler and more economical waste treatment forms [21].

Since the fish canning sector consumes significant amounts of water, one of the main practices to be considered will be the implementation of measures aimed at reducing water consumption, such as: vacuum suction systems on the reception of raw materials; flow control in cleaning operations by installation of cutting devices; use of warm water or humid air to fish defrosting; use of ice removal tank supernatant for cooling hot water; reuse of scalling fish water, after filtration, in the initial fish washing; use of high pressure and low flow cleaning systems; use of compressed air instead of water when possible; reuse and water recycling from and to non-critical operations; collection of fish waste in closed containers to prevent losses; dry transportation of waste; adjusting the size of nozzles; etc..

Most of the water used in fish processing industries of this type results in an effluent with high content of suspended solids and high levels of COD/BOD, as shown in Table I. The effluent have increased TSS due to the remains of fish, guts and sand and high COD and $\mathrm{BOD}_{5}$ due to organic substances such as blood, soluble proteins and fish oil. It is therefore important to introduce measures aimed at reducing the pollution load of the effluent to be treated, such as: solid waste recovery; use of vacuum cleaners to clean the fish; blood and fish remains collection to prevent reaching the wastewater collector; installation of trays or other containers for solid waste collection, before falling on the pavement; adequate coverage of wastewater drainage canals, to minimize the entrainment of solid waste; etc..

These pollution prevention measures are not the only ones possible for this industrial activity and also cannot be said that there is a unique solution applicable to all canned fish industries. The goal is to serve as a starting point for technicians of the different industrial units in the definition of additional integrated pollution prevention and control measures.

\section{Evaluation of Coagulation-Flocculation Treatment}

The results obtained during the sedimentation experiments showed that the formation of three different zones occurred: a floating solids layer, the clarified liquid ( $80 \%$ of total volume) and a bottom layer of solids. The characterization of the clarified liquid is shown in Table II. TSS, TOC and O\&G reductions of, respectively, $36 \%, 0 \%$ and $54 \%$ in relation to 
raw wastewater were obtained.

TABLE II: WASTEWATER CHARACTERISTICS BEFORE AND AFTER SEDIMENTATION EXPERIMENTS.

\begin{tabular}{ccc}
\hline \hline & \multicolumn{2}{c}{ Wastewater } \\
& Initial & After sedimentation \\
\hline TSS (mg/L) & $396 \pm 34$ & $254 \pm 14$ \\
TOC (mg/L) & $427 \pm 3$ & $435 \pm 3$ \\
O\&G (mg/L) & $759 \pm 327$ & $352 \pm 81$ \\
\hline \hline
\end{tabular}

This clarified effluent was then submitted to coagulation/flocculation tests. Two organic coagulant aids, RIPOL 070 and RIFLOC 1815, were tested at different dosages. These experiments were carried out at the $\mathrm{pH}$ of the raw wastewater. Table III shows a comparison of both coagulants effectiveness in removing TSS, TOC and O\&G from the wastewater.

TABLE III: TSS, TOC AND O\&G REMOVAL EFFICIENCIES OBTAINED AFTER ADDITION OF DIFFERENT DOSAGES OF RIFLOC 1815 AND RIPOL 070 TO THE WASTEWATER FROM THE SEDIMENTATION TEST.

\begin{tabular}{|c|c|c|c|c|c|c|c|c|}
\hline \multicolumn{9}{|c|}{ Removal efficiencies (\%) } \\
\hline \multirow{2}{*}{$\begin{array}{l}\text { Coagulant } \\
\text { dosage }(\mathrm{mg} / \mathrm{L})\end{array}$} & \multicolumn{5}{|c|}{ RIFLOC 1815} & \multicolumn{3}{|c|}{ RIPOL 070} \\
\hline & 20 & 50 & 100 & 150 & 200 & 100 & 200 & 400 \\
\hline TSS (mg/L) & 51.8 & 49.8 & 75.6 & 78.7 & 74.0 & 31.5 & 34.6 & 52.8 \\
\hline TOC (mg/L) & 7.2 & 8.5 & 15.7 & 18.5 & 18.7 & 0.0 & 0.0 & 0.0 \\
\hline $\mathrm{O} \& \mathrm{G}(\mathrm{mg} / \mathrm{L})$ & 98.4 & 98.2 & 98.9 & 99.3 & 99.3 & 85.8 & 87.1 & 87.9 \\
\hline
\end{tabular}

The TSS and TOC data suggest a significant difference between the two coagulant aids. Maximum TSS removal (79 \%) was achieved with a $150 \mathrm{mg} / \mathrm{L}$ dosage of RIFLOC 1815 , whereas when $400 \mathrm{mg} / \mathrm{L}$ of RIPOL 070 was used, only $53 \%$ of TSS was removed. From Table III, it is also possible to verify that increasing the concentration of RIFLOC 1815 from 20 to $200 \mathrm{mg} / \mathrm{L}$, an increase in TSS removal is observed. However, this increase is not so pronounced for higher concentrations, tending to stabilize between 100-200 mg/L. Regarding the TOC removal, it is possible to observe that in the coagulant dosages studied, the RIFLOC 1815 coagulant can only remove up to $19 \%$ and RIPOL 070 cannot get any removal of organic matter. This may be due to the fact that the coagulants themselves are organic materials, whose $1 \%$ working solutions have high TOC levels $(1555 \mathrm{mg} / \mathrm{L}$ for RIFLOC 1815 and $4748 \mathrm{mg} / \mathrm{L}$ for RIPOL 070). The use of high coagulant dosages may even contribute to the increase of wastewater TOC. The results in Table III show that both coagulants achieved excellent O\&G removal efficiencies. The highest O\&G removal $(99.3 \%)$ was obtained with $150-200 \mathrm{mg} / \mathrm{L}$ of RIFLOC 1815 , leading to O\&G values of $2.5 \mathrm{mg} / \mathrm{L}$ (approximately). The best removal observed with RIPOL 070 (400 mg/L) lead to O\&G concentration of 42 $\mathrm{mg} / \mathrm{L}$. From all the situations studied, it was found that the highest removal efficiencies were obtained with RIFLOC 1815. This compound contains $18 \%$ of an inorganic salt (aluminum polychloride), which may have had some influence on the obtained results. Thus, in order to verify this assumption, future studies will include additional tests with the application of other potential coagulation/flocculation aids, such as inorganic salts. Additionally, the solution $\mathrm{pH}$ and mixing values may also be varied.

\section{Evaluation of Biological Treatment}

By the results presented in Table I it is possible to observe that the effluent corresponding to the water of fish washing from plant A presents a relatively high $\mathrm{BOD}_{5} / \mathrm{COD}$ ratio $(0.8)$, indicating a high biodegradability, i.e., meaning that it can be treated easily by a biological process. So, the biological treatment of these fish canning wastewaters by activated sludge was performed to evaluate the removal efficiency of biodegradable compounds by microorganism's activity.

As previously mentioned, an initial growing period of the activated sludge took place for 20 days in batch mode, in order to obtain a biomass concentration of more than 1500 $\mathrm{mg}_{\mathrm{VSS}} / \mathrm{L}$ in the reactor. It was necessary a relatively long growing period since the weather conditions were a little adverse, with temperatures ranging between $6-11^{\circ} \mathrm{C}$. After having reached the desired biomass concentration, the reactor was operated in continuous mode.

The results for the two studied flow rates are presented in Table IV and indicate that the biological treatability of this type of wastewaters, under aerobic conditions, is very satisfactory, since lower TOC effluent values were achieved.

TABLE IV: REACTOR OPERATIONAL CONDITIONS FOR EACH FLOW RATE STUDIED AND WASTEWATER TOC BEFORE (FEED) AND AFTER (EFFLUENT) BIOLOGICAL TREATMENT.

\begin{tabular}{|c|c|c|c|c|c|c|}
\hline $\begin{array}{c}\text { Flow } \\
\text { rate } \\
(\mathrm{L} / \mathrm{h})\end{array}$ & $\mathrm{pH}$ & $\begin{array}{c}\mathrm{T} \\
\left({ }^{\circ} \mathrm{C}\right)\end{array}$ & $\begin{array}{c}\mathrm{TOC}_{\text {feed }} \\
(\mathrm{mg} / \mathrm{L})\end{array}$ & $\begin{array}{c}\mathrm{VSS} \\
(\mathrm{mg} / \mathrm{L})\end{array}$ & $\begin{array}{c}\text { SOUR } \\
\left(\mathrm{mg}_{\mathrm{O} 2} / \mathrm{g}_{\mathrm{VSs}} .\right. \\
\mathrm{min})\end{array}$ & $\begin{array}{c}\mathrm{TOC}_{\text {effluent }} \\
(\mathrm{mg} / \mathrm{L})\end{array}$ \\
\hline 0.75 & 7.8 & 17.3 & 594 & 4960 & 1.5 & 25 \\
\hline 1.2 & 7.5 & 17.6 & 696 & 4140 & 0.3 & 183 \\
\hline
\end{tabular}

In Fig. 5 the TOC removal efficiencies for each of the flow rates are presented.

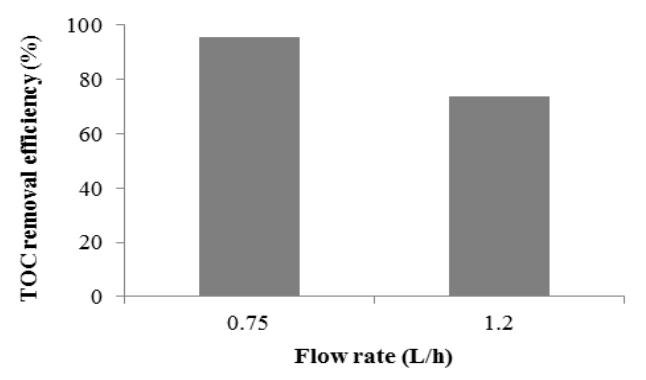

Fig. 5. TOC removal efficiency by biological treatment with flow rates of 0.75 and $1.2 \mathrm{~L} / \mathrm{h}$ (HRT of 8 and $5 \mathrm{~h}$, respectively).

From Fig. 5 it is possible to observe that the highest TOC removal efficiency $(96 \%)$ was achieved with the lowest flow rate $(0.75 \mathrm{~L} / \mathrm{h})$, which leads to the conclusion that the best removals are obtained for larger hydraulic retention times, since the activated sludge is in contact with the wastewater during more time.

By the results in Table IV, it is also possible to observe that the SOUR is higher for the lowest flow rate. Since the oxygen uptake rate (OUR) is related to the soluble substrate biodegradability and the autooxidation rate of the biological sludge in the reactor, a higher SOUR shoud be expected when operating the reactor at a higher HRT. In this situation, 
a greater amount of biomass was present in the reactor (4960 $\left.\mathrm{mg}_{\mathrm{VSS}} / \mathrm{L}\right)$, which corresponds to an increased sludge retention time, taking into account that the excess of the biomass purged out of the system was practically constant.

In order to determine the activated sludge accumulation over time in the secondary sedimentation tank, a study on the biomass production was also carried out. For that, the volume of activated sludge produced during a certain period of time for each flow rate was registered, and the sludge production was calculated as $0.38 \mathrm{~mL}$ per $\mathrm{mg}$ of TOC removed (3.9 and $5.6 \mathrm{~L} / \mathrm{d}$, respectively, for flow rates of 18 and $28.8 \mathrm{~L} / \mathrm{d}$ ). For a full-scale WWTP treating $100 \mathrm{~m}^{3} / \mathrm{d}$ of fish canning wastewater, this means a sludge production around $20.6 \mathrm{~m}^{3} / \mathrm{d}$ Assuming that the solids content increases to $6 \%$ after settling and thickening, about 1.2 ton/d of sludge need to be handled, including treatment and disposal.

This work showed the feasibility of using both sedimentation and coagulation-flocculation as operations to reduce significantly the content of suspended solids and oils and greases present in the wastewaters from fish canning industries and the use of aerobic biological process to treat its organic matter content. Further treatment of the clarified effluent could involve treatments such as Fenton oxidation, reverse osmosis and UV radiation disinfection, looking to obtain water with characteristics that allow its reuse in the industrial process.

\section{Conclusions}

In this work an overview of environmental situation of fish canning industries in northern Portugal has been made, with the characterization of several industrial wastewaters. In order to assist the industries in improving its production and environmental performance, a list of integrated pollution prevention and control measures to implement was proposed.

Finally, the wastewater treatment by chemical coagulation/flocculation and aerobic biological processes was evaluated. With sedimentation and chemical coagulation/flocculation treatment, TSS and O\&G total removal efficiencies of $86 \%$ and $99.7 \%$, respectively, were obtained using $150 \mathrm{mg} / \mathrm{L}$ of RIFLOC 1815 . Regarding the organic matter removal, the results obtained show the viability of the biological treatment with activated sludge for fish canning wastewaters treatment, leading to TOC removal efficiencies of $96 \%$ for HRT $=8 \mathrm{~h}$.

From the obtained results, it is possible to conclude that the chemical coagulation/flocculation is a good treatment for fish canning wastewaters, especially to remove oil and grease content, while the aerobic biological treatment leads to a very large decrease in the TOC value. So, these methods show to be a good starting point for a treatment sequence for this type of effluents.

\section{ACKNOWLEDGMENT}

The authors wish to thank Rivaz Química (Portugal) for coagulant aids and northern Portugal canneries for wastewater samples.

\section{REFERENCES}

[1] Castro and Melo, "A Indústria Conserveira em Portugal: constrangimentos, oportunidades, desafios e inovação," ANICP Associação Nacional dos Industriais de Conservas de Peixe, May 2010.

[2] Handbook for the prevention and minimisation of waste and valorisation of by-products in European agro-food industries, AWARENET, 2005.

[3] Cleaner Production Assessment in Fish Processing, COWI Consulting Engineers and Planners AS, UNEP, 2000.

[4] IPPC - Reference Document on Best Available Techniques in the Food, Drink and Milk Industries, Comissão Europeia, August 2006.

[5] K. Bensadok, M. Belkacem, and G. Nezzal, "Treatment of cutting oil/water emulsion by coupling coagulation and dissolved air flotation," Desalination, vol. 206, pp. 440-448, 2007.

[6] H. Zhu and Y. Zhu, "Study of PVDF tubular ultrafiltration membrane for separating oil/water emulsion and effect of cleaning method on membrane," Modern Appl. Sci, vol. 3, pp. 144-150, January 2009.

[7] P. Canizares, F. Martínez, J. Lobato, and M. A. Rodrigo, "Break-up of oil-in-water emulsions by electrochemical techniques," J. Hazard. Mat, vol. 145, pp. 233-240, June 2007.

[8] G. Ríos, C. Pazos, and J. Coca, "Destabilization of cutting oil emulsions using inorganic salts as coagulants," Colloids Surf. A, vol. 138, pp. 383-389, July 1998.

[9] K. Matsumiya, K. Nakanishi, and Y. Matsumura, "Destabilization of protein-based emulsions by diglycerol esters of fatty acids - The importance of chain length similarity between dispersed oil molecules and fatty acid residues of the emulsifier," Tetrahedron Lett, vol. 25, pp. 773-780, 2011.

[10] A. Pinotti and N. Zaritzky, "Effect of aluminum sulfate and cationic polyelectrolytes on the destabilization of emulsified wastes," Waste Manag, vol. 21, pp. 535-542, 2001.

[11] J. Lim, T. Kim, and S. Hwang, "Treatment of fish-processing wastewater by co-culture of Candida rugopelliculosa and Brachionus plicatilis," Water Res, vol. 37, pp. 2228-2232, 2003.

[12] A. M. Corral, J. L. Campos, M. Sánchez, R. Méndez, and J. M. Lema, "Combined System for Biological Removal of Nitrogen and Carbon from a Fish Cannery Wastewater," J. Environ. Eng., vol. 129, pp. 826-833, 2003.

[13] V. Oyanedel, J. M. Garrido, J. M. Lema, and R. Méndez, “A membrane assisted hybrid bioreactor for the post treatment of an anaerobic effluent from a fish canning factory," Water Sci. Technol, vol. 48. no. 6, pp. 301-309, 2003.

[14] P. Artiga, G. G. Toriello, R. Méndez, and J. M. Garrido, "Use of a hybrid membrane bioreactor for the treatment of saline wastewater from a fish canning factory," Desalination, vol. 221, pp. 518-525, 2008.

[15] A. D. Mora, J. L. Campos, A. M. Corral, and R. Méndez, “Anammox process for nitrogen removal from anaerobically digested fish canning effluents,"Water Sci. Technol, vol. 53, pp. 265-274, 2006.

[16] P. Chowdhury, T. Viraraghavan, and A. Srinivasan, "Biological treatment processes for fish processing wastewater - A review," Biores. Technol, vol. 101, pp. 439-449, 2010.

[17] R. E. Carawan, J. V. Chambers, and J. V. Zall, Seafood water and wastewater management, North Carolina Agricultural Extension Services, Raleigh, NC, 1979.

[18] M. T. Pérez, P. B. Hernández, D. C. E. Barrera, G. R. Morales, and R. R. Natividad, "Treatment of industrial effluents by a continuous system: Electrocoagulation - Activated sludge," Biores. Technol, vol. 101, pp.7761-7766, May 2010.

[19] Pollution Prevention in Food Canning Processes, Regional Activity Centre for Cleaner Production (RAC/CP), Mediterranean Action Plan, March 2001.

[20] Standard Methods for the Examination of Water and Wastewater, 20th ed., APHA, AWWA, WEF, American Public Health Association, American Water Works Association, Water Pollution Control Federation, Washington, DC., 1998.

[21] J. Zufía, and G. Aurrekoetxea, "Integrated processing of fish canning industry wastewater: the EFLUCON project," J. Aquat. Food Prod. Technol, vol. 11, pp. 303-315, 2002. 